\title{
Sebaran Fosfor Anorganik Partikulat di Muara Sungai Banjir Kanal Barat Semarang
}

\author{
Natalia Jelita Tarigan, Baskoro Rochaddi, Petrus Subardjo, Lilik Maslukah* \\ Departemen Oseanografi, Fakultas Perikanan dan IImu Kelautan, Universitas Diponegoro \\ Jl. Prof.H.Soedarto S.H, Tembalang,Semarang, Jawa Tengah 50275 Indonesia \\ ${ }^{*}$ Corresponding author, e-mail : lilik_masluka@yahoo.com
}

\begin{abstract}
ABSTRAK: Muara Sungai Banjir Kanal Barat Semarang merupakan wilayah yang berpotensi mengalami eutrofikasi akibat buangan limbah rumah tangga dan industri. Penelitian sebelumnya lebih banyak pada fosfor dalam sedimen dasar dan fosfat terlarut, sedangkan kandungan fosfor anorganik dalam total suspended solid (TSS) di perairan muara dan laut belum banyak dibahas.. Tujuan dari penelitian ini adalah mengetahui sebaran fosfor anorganik partikulat (PIP) di perairan sekitar muara Sungai Banjir Kanal Barat Semarang. Pengambilan sampel dilakukan pada lapisan permukaan (kedalaman 0,5 m). Analisis TSS dilakukan dengan metode gravimetri. Ekstraksi asam PIP dilakukan berdasarkan metodologi ekstraksi konvensional, menggunakan $1 \mathrm{M} \mathrm{HCl}$, diikuti oleh prosedur untuk menurunkan keasaman dan dianalisis dengan metode spectrophotometric phosphomolybdenum blue pada panjang gelombang $880 \mathrm{~nm}$. Konsentrasi PIP yang didapatkan berkisar antara 0,42-1,28 $\mu \mathrm{mol} / \mathrm{g}$ dengan nilai rata-rata sebesar $0,54 \mathrm{\mu mol} / \mathrm{g}$. Sebaran PIP dipengaruhi oleh arus pasang surut, total suspended solid (TSS) dan salinitas. Sebaran PIP dominan ke arah barat - barat laut karena pengaruh arus pada saat pasang menuju surut. Konsentrasi PIP menurun seiring berkurangnya konsentrasi TSS dan meningkatnya nilai salinitas.
\end{abstract}

Kata kunci: Sebaran; Fosfor Anorganik Partikulat; Muara Banjir Kanal Barat

\section{The Distribution of Particulate Inorganic Phosphorus in The Banjir Kanal Barat Estuary Semarang}

ABSTRACT: The Banjir Kanal Barat estuary is an area that has the potential to have eutrophication due to receiving household and industrial waste disposal. Previous research was more on phosphorus in bottom sediments and dissolved phosphate, while the content of inorganic phosphorus in total suspended solids (TSS) in the estuary and marine waters has not been widely discussed. The purpose of this study was to determine the distribution of particulate inorganic phosphorus (PIP) in the waters around the Banjir Kanal Barat estuary. Sampling was carried out on the surface layer $(0.5$ $m$ depth). TSS analysis was performed using the gravimetric method. PIP acid extraction was carried out based on conventional extraction methodology, which required $1 \mathrm{M} \mathrm{HCl}$, followed by a procedure to reduce acidity and analyzed by spectrophotometric phosphomolybdate blue method at a wavelength of $880 \mathrm{~nm}$. PIP concentrations obtained ranged from 0,42 $\mu \mathrm{mol} / \mathrm{g}-1,28 \mu \mathrm{mol} / \mathrm{g}$ with an average value of $0.54 \mu \mathrm{mol} / \mathrm{g}$. Distribution of PIP is influenced by tidal currents, total suspended solid (TSS) and salinity. Distribution of PIP is dominant to west-northwest direction due to the influence of currents at ebb current. PIP concentration decreases with decreasing TSS concentration and increasing salinity.

Keywords: Distribution; Particulate Inorganic Phosphorus; Banjir Kanal Barat Estuary

\section{PENDAHULUAN}

Muara merupakan wilayah terjadinya proses biogeokimia yang membawa dan mengubah fluks nutrien dari darat ke laut. Tidak hanya nutrien yang terlarut, nutrien partikulat juga mengalami perubahan dalam sistem perairan air tawar menuju air laut yang dipengaruhi oleh adanya proses hidrologi (Sundareshwar dan Morris, 1999; Jickells, 2005). Fosfor (P) adalah salah satu nutrien yang penting dalam mengatur produksi primer di perairan. $\mathrm{P}$ di perairan ditemukan dalam bentuk organik dan anorganik baik yang terlarut maupun partikulat. Lebih dari $90 \% \mathrm{P}$ yang dibawa oleh aliran sungai 
ke muara adalah fosfor yang mengalami proses adsorpsi pada padatan tersuspensi (total suspended solid / TSS), atau disebut dengan fosfor partikulat (Föllmi, 1996; Jordan et al., 2008). Ketersediaan $P$ pada TSS dipengaruhi oleh proses adsorpsi dan desorpsi. Proses tersebut terjadi sepanjang gradien salinitas sehingga mempengaruhi distribusi fosfor di perairan (Deborde et al., 2007). Fosfor anorganik partikulat (particulate inorganic phosphorus / PIP) merupakan jenis $P$ yang banyak terangkut dari sungai ke muara, khususnya terdapat dalam butiran mineral, teradsorpsi pada partikel biotik dan abiotik serta sebagai penyimpanan fosfor intraseluler seperti fosfat, pirofosfat dan polifosfat. Fosfor yang diabsorpsi oleh plankton di permukaan perairan merupakan sumber utama PIP (Yoshimura et al., 2007).

Perkembangan industri dan peningkatan aktivitas rumah tangga di sekitar aliran Banjir Kanal Barat Semarang menyebabkan perairan tersebut berpotensi mengalami masalah eutrofikasi oleh dampak dari buangan limbah industri yang mengandung nutrien $P$. Sebagian besar penelitian sebelumnya di Muara Sungai Banjir Kanal Barat Semarang lebih berfokus pada fosfat terlarut dan fosfat dalam sedimen. Penelitian mengenai fosfat terlarut telah dilakukan oleh Oktaviani et al. (2015), Tungka et al. (2016) dan Haeruddin et al. (2019), serta penelitian mengenai fosfat dalam sedimen telah dilakukan oleh Maslukah et al. (2017) dan Ariawan et al. (2019). Sedangkan fosfor anorganik pada total suspended solid (TSS) lebih sedikit dibahas. Mengingat PIP merupakan sumber utama ketersediaan DIP bagi produktivitas primer di laut (Li et al., 2017) dan dominan berasal dari muara sungai (Ruttenberg, 2003), maka penting untuk mengetahui sebaran PIP di Muara Sungai Banjir Kanal Barat Semarang.

\section{MATERI DAN METODE}

Materi yang digunakan dalam penelitian ini adalah sampel air laut yang diambil dari Muara Sungai Banjir Kanal Barat Semarang dan didukung oleh data sekunder seperti data pasang surut, data arus dan batimetri. Pengambilan sampel dilakukan pada tanggal 3 Oktober 2019 pada kondisi pasang menuju surut. Penentuan titik lokasi penelitian dilakukan dengan metode purposive sampling menggunakan GPS (global positioning system) yang ditunjukkan pada Gambar 1.

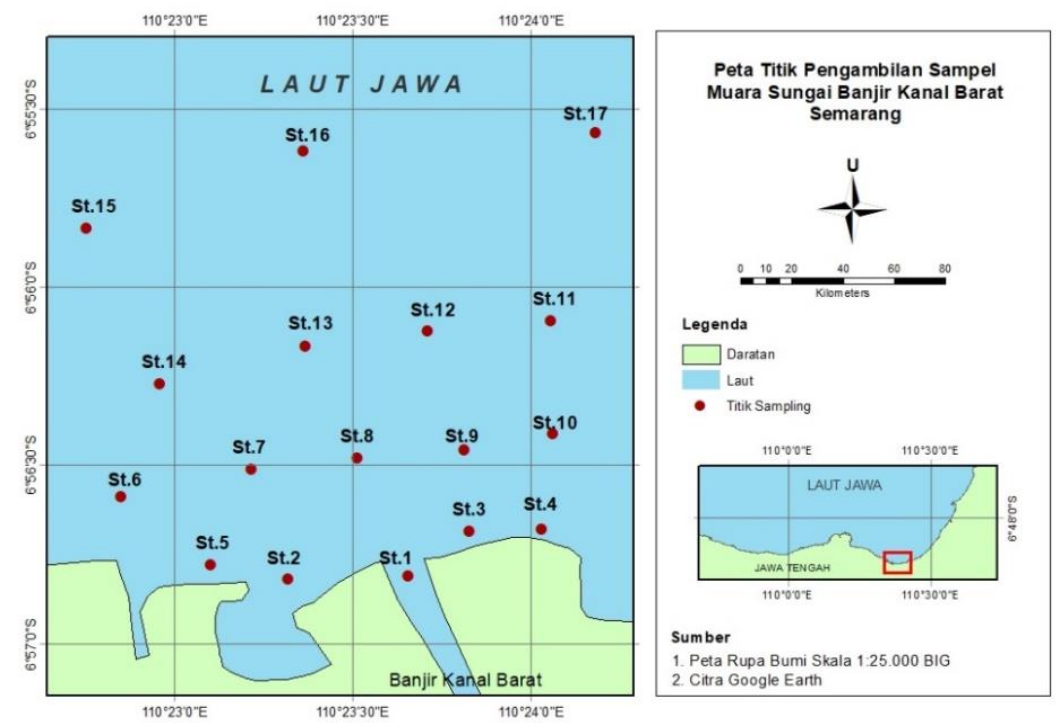

Gambar 1. Titik Sampling Lokasi Penelitian

Pengambilan sampel air laut dilakukan pada 17 stasiun menggunakan botol nansen di lapisan permukaan (kedalaman 0,5 m) (Kong et al., 2018) dan disimpan pada botol sampel polyethylene (PE) $1000 \mathrm{ml}$ (Wulandari et al., 2014). Analisis konsentrasi TSS dilakukan dengan metode gravimetri menggunakan kertas saring ashless dengan ukuran pori 2,5 $\mu \mathrm{m}$ (Whatman). Volume sampel air laut yang disaring adalah sebanyak $200 \mathrm{ml}$. Kemudian residu yang tertahan pada saringan dikeringkan 
pada suhu $103^{\circ} \mathrm{C}$ hingga $10^{\circ} \mathrm{C}$ selama \pm 10 menit dan ditimbang sebanyak 3 kali pengulangan untuk mendapatkan berat konstan. Konsentrasi TSS dihitung dengan rumus:

$$
\operatorname{TSS}(\mathrm{mg} / \mathrm{l})=\frac{(A-B)}{\text { Volume sampel air }(l)}
$$

Keterangan: $A$ = berat kertas saring + residu kering $(\mathrm{mg}) ; \mathrm{B}=$ berat kertas saring $(\mathrm{mg})$.

Sampel yang telah difiltrasi kemudian diekstraksi dan dikocok selama \pm 18 jam dengan $10 \mathrm{ml}$ larutan $\mathrm{HCl} 1 \mathrm{M}$ dan disimpan di tempat gelap bersuhu ruang $\left(25^{\circ} \mathrm{C}\right)$. Lalu disentrifugasi selama \pm 15 menit dan dipisahkan dari residunya (Labry et al., 2013). Hasil ekstraksi diencerkan dengan $20 \mathrm{ml}$ aquadest sebelum penentuan nilai absorbansi. Hal ini dilakukan karena pengembangan warna melalui reaksi phosphomolybdate blue akan terhambat dalam kondisi yang sangat asam (Makoto et al., 2016). Larutan standar $P$ yang digunakan dalam analisis konsentrasi PIP terdiri dari 5 konsentrasi yang berbeda yakni $0,18 \mu \mathrm{M}, 0,3 \mu \mathrm{M}, 1,2 \mu \mathrm{M}, 3 \mu \mathrm{M}$ dan $6 \mu \mathrm{M}$. Nilai absorbansi larutan standar, blank dan sampel ditentukan menggunakan metode spektrofotometri fosfomolibdenum biru pada panjang gelombang $880 \mathrm{~nm}$ (Labry et al., 2013). Nilai absorbansi larutan standar kemudian digunakan untuk menggambar kurva regresi. Konsentrasi PIP dihitung dengan rumus (Maslukah et al., 2017)

$$
\mathrm{PIP}(\mu \mathrm{mol} / \mathrm{g})=\frac{C \times V}{W}
$$

Keterangan: $\mathrm{C}=$ nilai konsentrasi hasil pembacaan spektrofotometri $(\mu \mathrm{M}) ; \mathrm{V}=$ volume larutan pengekstrak yang digunakan (I); $\mathrm{W}=$ berat sedimen yang diekstrak $(\mathrm{g})$.

Data pasang surut diolah dengan metode admiralty 15 hari (Hidayah dan Mahatmawati, 2010). Simulasi model arus diolah menggunakan hydrodynamic module dalam software pemodelan 2D dengan inputan data berupa data time series pasang surut dan data mesh batimetri yang akan menghasilkan output berupa current speed dan current direction dalam bentuk area series dengan 360 time step yang menyesuaikan data time series pasang surut. Data arus yang akan divalidasi dengan data arus lapangan adalah data komponen kecepatan arus arah $\mathrm{U}$ (barat-timur/E) dan arah $\mathrm{V}$ (utara-selatan/N) serta data elevasi pasang surut. Validasi hasil model dilakukan menggunakan metode RMSE-observations standard deviation ratio (RSR), dengan persamaan (Moriasi et al., 2007) berikut:

$$
\mathrm{RSR}=\frac{R M S E}{\operatorname{STDEV}_{\text {obs }}}=\frac{\left[\sqrt{\left.\sum_{i=1}^{n}\left(Y_{i}^{\text {obs }}-Y_{i}^{\text {sim }}\right)^{2}\right]}\right]}{\left[\sqrt{\sum_{i=1}^{n}\left(Y_{i}^{\text {obs }}-Y^{\text {mean }}\right)^{2}}\right]}
$$

\section{HASIL DAN PEMBAHASAN}

Pola arus hasil pemodelan di Perairan Muara Sungai Banjir Kanal Barat Semarang mewakili kondisi arus saat pasang menuju surut yang menggambarkan pergerakan arus laut yang bergerak dari arah timur ke arah barat - barat laut $\left(250^{\circ}-300^{\circ}\right)$ dengan kecepatan rata-rata sebesar $0,056 \mathrm{~m} / \mathrm{s}$. Pola arus dapat dilihat pada Gambar 2. Pergerakan arus laut dari timur ke barat berkaitan dengan waktu pengambilan data yakni pada saat Musim Peralihan II dimana angin lebih dominan bertiup dari timur ke barat. Arus maksimum berada di sekitar perairan laut yakni sebesar 0,075- 0,12 m/s, dengan kecepatan terbesar pada stasiun 16 dan 17 yang merupakan daerah perairan terdalam dari titik lokasi pengambilan data. Kecepatan arus di sekitar muara adalah sebesar 0,08-0,09 m/s sedangkan arus terkecil berada di sekitar perairan Pantai Marina (stasiun 2 dan 5) dengan kecepatan sebesar 0,016 m/s - 0,048 m/s. Validasi model dengan rumus RSR dilakukan terhadap komponen kecepatan arus arah V (utaraselatan) dan arah $\mathrm{U}$ (barat-timur). Nilai RSR untuk komponen kecepatan arus arah $\mathrm{V}$ adalah sebesar 0,60 dan untuk komponen kecepatan arus arah U adalah sebesar 0,53. Menurut Moriasi et al. (2007), model dianggap layak digunakan apabila nilai RSR bernilai $>0,7$.

Konsentrasi TSS di Muara Sungai Banjir Kanal Barat Semarang berkisar antara 60,20 mg/l $104,00 \mathrm{mg} / \mathrm{l}$ dengan rata-rata sebesar $74,86 \mathrm{mg} / \mathrm{l}$. Dari hasil perhitungan konsentrasi TSS diketahui bahwa TSS cukup bervariasi dari 17 stasiun. TSS tertinggi terdapat pada stasiun 1 dan konsentrasi terendah terdapat pada stasiun 16. TSS dari muara (stasiun 1) dominan menyebar ke arah barat- 
barat laut (stasiun 2, 5, 6, 14 dan 15) sedangkan rendah di arah timur perairan (stasiun 4, 10, 11 dan 17) yang dapat dilihat pada Gambar 3.

Konsentrasi PIP di Muara Sungai Banjir Kanal Barat berkisar antara 0,42 $\mu \mathrm{mol} / \mathrm{g}-1,28 \mu \mathrm{mol} / \mathrm{g}$ dengan rata-rata sebesar $0,58 \mu \mathrm{mol} / \mathrm{g}$. Dari hasil perhitungan konsentrasi PIP diketahui bahwa PIP memiliki variasi yang kecil dari stasiun 2 hingga stasiun 17. Konsentrasi PIP tertinggi terdapat pada stasiun 1 dan konsentrasi terendah terdapat pada stasiun 4 dan 16. Sama seperti TSS, konsentrasi PIP juga dominan menyebar ke arah barat-barat laut (stasiun 2, 7, 14 dan 15) sedangkan rendah di arah timur perairan (stasiun 4, 10, 11 dan 17) yang dapat dilihat pada Gambar 4. Nilai salinitas berkisar antara $25 \%-34 \%$. Nilai salinitas tertinggi berada pada stasiun 16 dan 11 sedangkan nilai terendah berada pada stasiun 1. Nilai konsentrasi TSS, PIP dan salinitas di Muara Sungai Banjir Kanal Barat Semarang dapat dilihat pada Tabel 1.
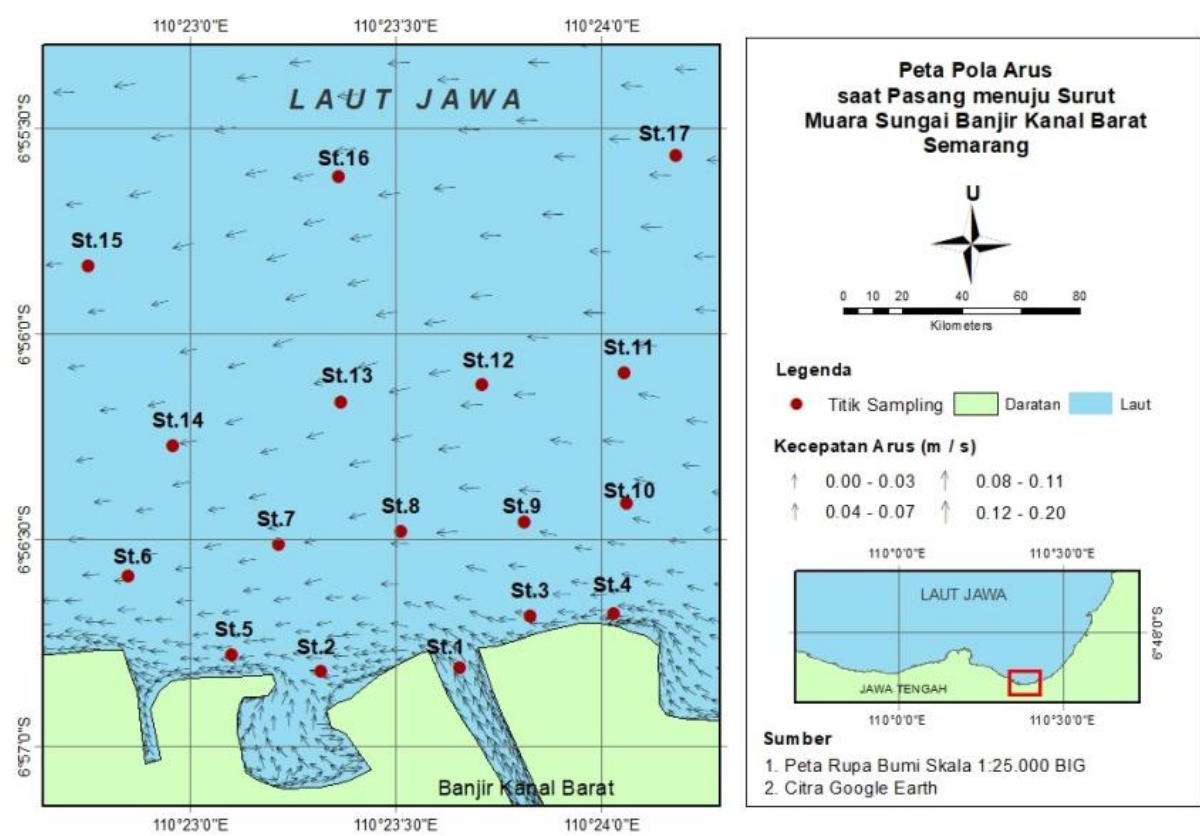

Gambar 2. Pola Arus Perairan Muara Sungai Banjir Kanal Barat saat Pasang menuju Surut
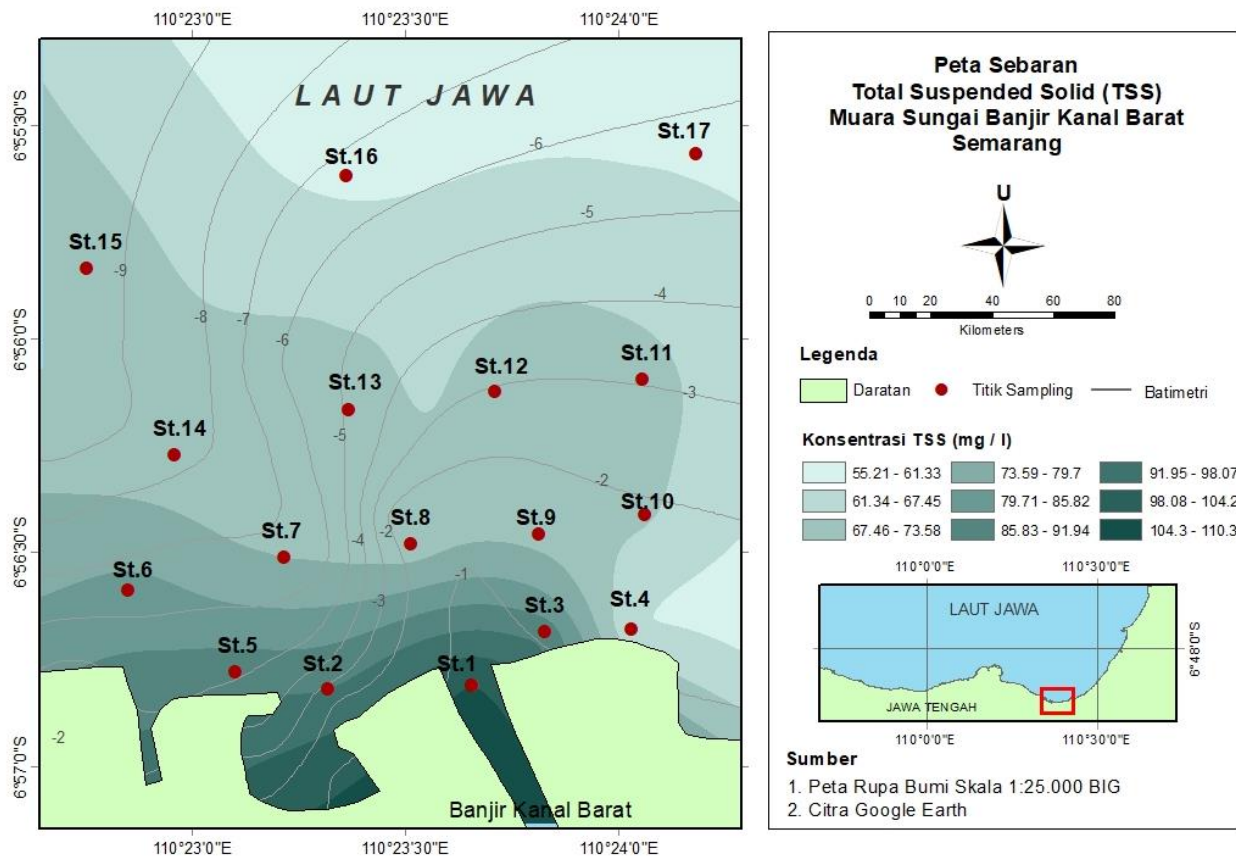

Gambar 3. Sebaran Konsentrasi TSS di Perairan Muara Sungai Banjir Kanal Barat 
Tabel 1. Konsentrasi TSS, PIP dan Salinitas di Muara Sungai Banjir Kanal Barat Semarang

\begin{tabular}{|c|c|c|c|c|c|}
\hline No. & Latitude & Longitude & Konsentrasi TSS (mg/l) & $\begin{array}{l}\text { Konsentrasi PIP } \\
(\mu \mathrm{mol} / \mathrm{g})\end{array}$ & $\begin{array}{c}\text { Salinitas } \\
(\%)\end{array}$ \\
\hline 1 & $6^{\circ} 56^{\prime} 48,60^{\prime \prime}$ & $110^{\circ} 23^{\prime} 39,46^{\prime \prime}$ & 104,00 & 1,28 & 25 \\
\hline 2 & $6^{\circ} 56^{\prime} 49,04 "$ & $110^{\circ} 23^{\prime} 19,28^{\prime \prime}$ & 92,00 & 0,59 & 30 \\
\hline 3 & $6^{\circ} 56^{\prime} 41,05^{\prime \prime}$ & $110^{\circ} 23^{\prime} 48,91^{\prime \prime}$ & 90,50 & 0,57 & 30 \\
\hline 4 & $6^{\circ} 56^{\prime} 40,56^{\prime \prime}$ & $110^{\circ} 24^{\prime} 01,86^{\prime \prime}$ & 62,23 & 0,42 & 31 \\
\hline 5 & $6^{\circ} 56^{\prime} 46,64 "$ & $110^{\circ} 23^{\prime} 06,17^{\prime \prime}$ & 88,67 & 0,50 & 31 \\
\hline 6 & $6^{\circ} 56^{\prime} 35,24 "$ & $110^{\circ} 22^{\prime} 51,17^{\prime \prime}$ & 81,34 & 0,52 & 32 \\
\hline 7 & $6^{\circ} 56^{\prime} 30,58 "$ & $110^{\circ} 23^{\prime} 13,06^{\prime \prime}$ & 73,50 & 0,57 & 32 \\
\hline 8 & 656'28,58" & $110^{\circ} 23^{\prime} 30,92^{\prime \prime}$ & 70,17 & 0,60 & 31 \\
\hline 9 & $6^{\circ} 56^{\prime} 27,30 "$ & $110^{\circ} 23^{\prime} 48,82^{\prime \prime}$ & 71,67 & 0,59 & 31 \\
\hline 10 & $6^{\circ} 56^{\prime} 24,51^{\prime \prime}$ & $110^{\circ} 24^{\prime} 03,77^{\prime \prime}$ & 68,12 & 0,54 & 31 \\
\hline 11 & $6^{\circ} 56^{\prime} 05,54 "$ & $110^{\circ} 24^{\prime} 03,44^{\prime \prime}$ & 68,57 & 0,51 & 34 \\
\hline 12 & $6^{\circ} 56^{\prime} 07,31^{\prime \prime}$ & $110^{\circ} 23^{\prime} 42,67^{\prime \prime}$ & 70,12 & 0,58 & 33 \\
\hline 13 & $6^{\circ} 56^{\prime} 09,88^{\prime \prime}$ & $110^{\circ} 23^{\prime} 22,13^{\prime \prime}$ & 70,39 & 0,59 & 33 \\
\hline 14 & $6^{\circ} 56^{\prime} 16,22 "$ & $110^{\circ} 22^{\prime} 57,59^{\prime \prime}$ & 70,43 & 0,59 & 32 \\
\hline 15 & $6^{\circ} 55^{\prime} 49,91^{\prime \prime}$ & $110^{\circ} 22^{\prime} 45,34^{\prime \prime}$ & 70,36 & 0,59 & 33 \\
\hline 16 & $6^{\circ} 55^{\prime} 36,91^{\prime \prime}$ & $110^{\circ} 23^{\prime} 21,79^{\prime \prime}$ & 60,20 & 0,43 & 34 \\
\hline 17 & $6^{\circ} 55^{\prime} 33,86^{\prime \prime}$ & $110^{\circ} 24^{\prime} 11,02^{\prime \prime}$ & 60,29 & 0,45 & 33 \\
\hline
\end{tabular}
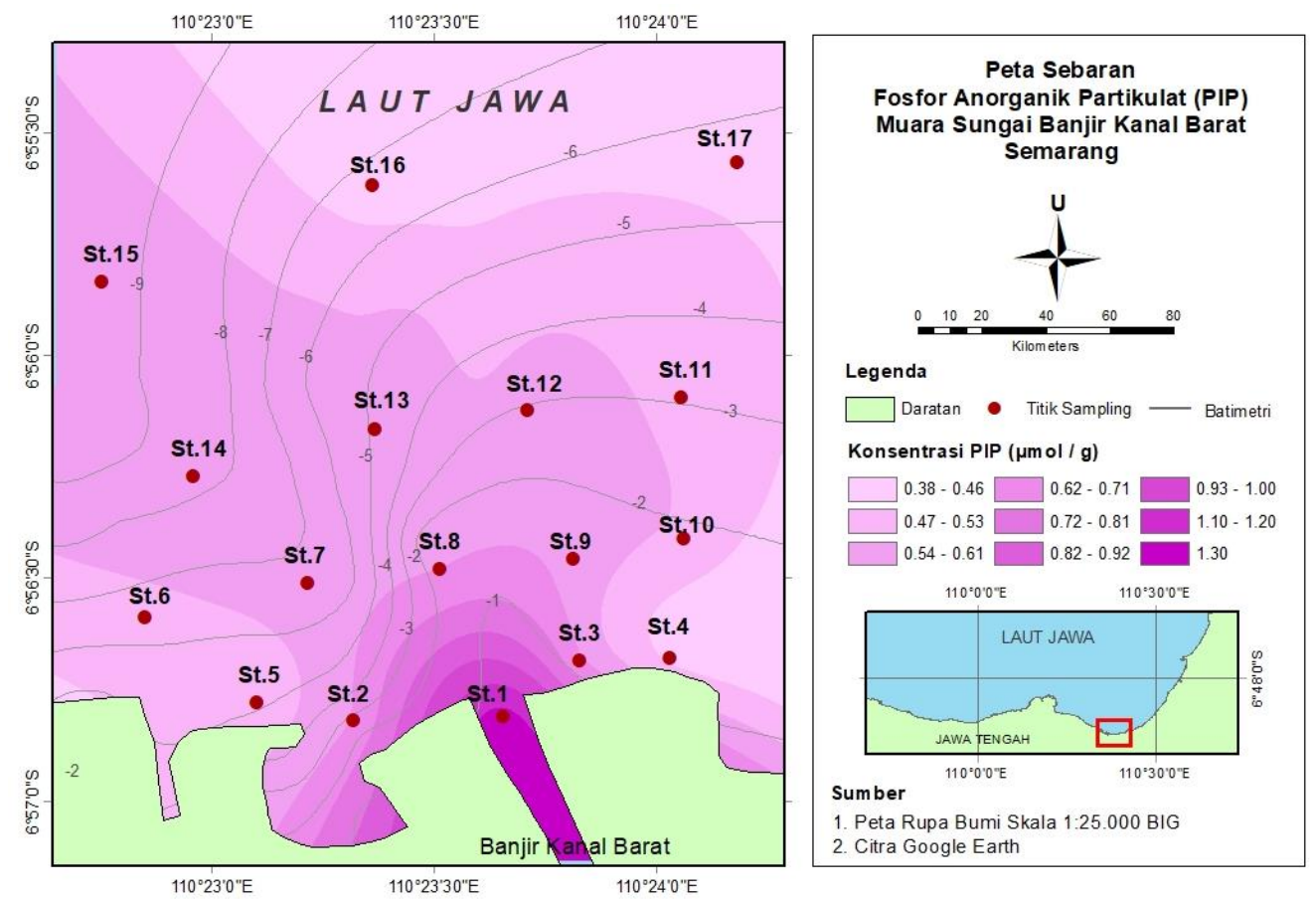

Gambar 4. Sebaran Konsentrasi PIP di Perairan Muara Sungai Banjir Kanal Barat 
Hubungan antara PIP dengan TSS disajikan pada Tabel 2, dimana konsentrasi PIP berkorelasi positif terhadap konsentrasi TSS. Nilai tersebut menunjukkan bahwa PIP berhubungan kuat dengan TSS, dimana ketika konsentrasi TSS menurun maka konsentrasi PIP juga akan menurun. Konsentrasi PIP rata-rata di Muara Sungai Banjir Kanal Barat Semarang juga menurun secara eksponensial sepanjang interval salinitas : 0,81 $\mathrm{mol} / \mathrm{g}$ (salinitas 25-30 \%o); 0,54 $\mathrm{mmol} / \mathrm{g}$ (salinitas 31-32 \%o) dan 0,52 $\mu \mathrm{mol} / \mathrm{g}$ (salinitas 33-34 \%o). PIP berkorelasi negatif terhadap salinitas (Tabel 2) yang menunjukkan bahwa PIP di Muara Sungai Banjir Kanal Barat memiliki hubungan yang sangat kuat dengan salinitas, dimana peningkatan nilai salinitas di perairan tersebut berpengaruh besar terhadap penurunan konsentrasi PIP.

Tabel 2. Hubungan antara PIP dengan TSS dan Salinitas

\begin{tabular}{ll}
\hline \multicolumn{1}{c}{ Persamaan Regresi } & \multicolumn{1}{c}{$R^{2}$} \\
\hline PIP $=0,0105($ TSS $)-0,2045$ & $R^{2}=0,47, r=0,68$, \\
$P I P=9.6016 e^{-0.09 \text { (Salinitas) }}$ & $R^{2}=0.6118, r=0,81$ \\
\hline
\end{tabular}

Pola arus saat sampling yang mewakili kondisi pasang menuju surut bergerak dari arah timur ke barat - barat laut dan arus yang bergerak keluar muara menuju laut menyebabkan TSS dari muara menyebar ke arah barat perairan laut. TSS yang mengikat PIP menyebabkan sebaran PIP mengikuti pola arus dominan tersebut. Kecepatan arus di lokasi penelitian pada saat pasang menuju surut terpantau cenderung bervariasi di sekitar perairan pantai karena pengaruh dari morfologi pantai, yakni dangkal di sekitar Pantai Marina dan semakin dalam ke arah timur. Diketahui pula bahwa semakin ke arah laut dan semakin bertambahnya kedalaman, maka kecepatan arus semakin besar. Namun arus yang besar di perairan laut menyebabkan konsentrasi PIP yang didapatkan semakin kecil karena di perairan laut bersalinitas yang tinggi, fosfor $(P)$ yang terikat pada TSS akan mengalami proses desorpsi dan terlepas ke perairan (atau disebut dengan DIP / fosfor anorganik terlarut). Proses penurunan konsentrasi PIP dari muara menuju laut mengindikasikan bahwa sumber PIP berasal dari aliran sungai.

Hubungan antara PIP dan TSS yang berbanding lurus menunjukkan TSS berpengaruh besar terhadap konsentrasi PIP di perairan. Pengaruh TSS terhadap PIP juga diperkuat dari penelitian Li et al. (2017), yang mendapatkan hasil bahwa PIP berhubungan kuat dengan TSS (nilai $R^{2}=0,56$ ). Konsentrasi TSS yang rendah di laut menyebabkan konsentrasi PIP juga menjadi rendah. Hal ini terjadi karena semakin ke laut lepas maka perairan akan semakin dalam sehingga mengakibatkan penurunan konsentrasi PIP pada TSS dengan kata lain terjadi pengenceran fosfor oleh air laut. Menurut Paytan dan McLaughlin (2007), senyawa fosfor yang terikat di sedimen dapat mengalami dekomposisi dengan bantuan bakteri maupun melalui proses abiotik menghasilkan senyawa fosfat terlarut yang dapat mengalami difusi kembali ke kolom air.

Berdasarkan sebaran PIP yang menurun ke arah laut lepas, menunjukkan bahwa terdapat faktor lain yang mempengaruhi penyebaran konsentrasinya, yakni pengaruh dari salinitas air laut. Konsentrasi PIP berbanding terbalik dengan nilai salinitas, dimana konsentrasi PIP menurun sepanjang gradien salinitas (nilai korelasi negatif). Penelitian Zee et al. (2007) juga mendapatkan hasil bahwa konsentrasi PIP menurun secara eksponensial seiring bertambahnya salinitas. Selain itu, hasil penelitian Nemery dan Garnier (2007) juga menyebutkan bahwa dalam gradien salinitas dari 0 hingga 30, konsentrasi PIP berkurang sebesar 30\%. Adanya korelasi negatif antara PIP dengan salinitas menunjukkan bahwa sumber utama PIP di perairan berasal dari aliran air sungai (Montani et al., 1998 dalam Maslukah et al., 2014).

\section{KESIMPULAN}

Berdasarkan hasil penelitian didapatkan bahwa sebaran fosfor anorganik partikulat (PIP) di perairan Muara Sungai Banjir Kanal Barat Semarang dipengaruhi oleh arus pasang surut, total suspended solid (TSS) dan salinitas. Sebaran PIP dominan ke arah barat - barat laut karena pengaruh arus saat pasang menuju surut. Konsentrasi PIP berkorelasi positif dengan TSS dan berkorelasi negatif dengan salinitas yang menunjukkan bahwa sumber utama PIP di perairan tersebut berasal dari sungai. 


\section{DAFTAR PUSTAKA}

Ariawan, F., Haeruddin \& Rahman, A., 2019, Hubungan Zat Hara $\left(\mathrm{HNO}_{3}{ }^{-}\right.$dan $\left.\mathrm{PO}_{4}{ }^{-}\right)$Sedimen terhadap Kelimpahan dan Keanekaragaman Makrozoobentos di Sungai Banjir Kanal Barat, Semarang, Journal of Maquares, 8(4):300-308.

Deborde, J., Anschutz, P., Chaillou, G., Etcheber, H., Commarieu, M., Lecroart, P. \& Abril, G., 2007. The Dynamics of Phosphorus in Turbid Estuarine Systems: Example of The Gironde Estuary (France). Limnol. Oceanogr., 52(2):862-872.

Föllmi, K. B., 1996, The Phosphorus Cycle, Phosphogenesis and Marine Phosphate-Rich Deposits, Earth Science Review, 40:55-124.

Haeruddin., Purnomo, P.W. \& Febrianto, S., 2019, Beban Pencemaran, Kapasitas Asimilasi dan Status Pencemaran Estuari Banjir Kanal Barat, Kota Semarang, Jawa Tengah, Journal of Natural Resources and Environmental Management, 9(3):723-735.

Hidayah, Z. \& Mahatmawati, A.D., 2010, Perbandingan Fluktuasi Muka Air Laut Rerata (MLR) di Perairan Pantai Utara Jawa Timur dengan Perairan Pantai Selatan Jawa Timur, Jurnal KELAUTAN, 3(2):159-167.

Jickells, T., 2005, External Inputs as A Contributor to Eutrophication Problems, Journal of Sea Research 54:58-69.

Jordan, T.E., Cornwell, J.C., Boynton, W.R. \& Anderson, J.T., 2008, Changes in Phosphorus Biogeochemistry along An Estuarine Salinity Gradient: The Iron Conveyer Belt, Limnol. Oceanogr., 53(1):172-184.

Kong, M., Chao, J., Zuang, W., Wang, P., Wang, C., Hou, J., Wu, Z., Wang, L., Gao, G. \& Wang, Y., 2018, Spatial and Temporal Distribution of Particulate Phosphorus and Their Correlation with Environmental Factors in a Shallow Eutrophic Chinese Lake (Lake Taihu), International Journal of Environmental Research and Public Health,15:1-12.

Labry, C., Youenou, A., Delmas, D. \& Michelon, P., 2013, Addressing The Measurement of Particulate Organic and Inorganic Phosphorus in Estuarine and Coastal Waters, Continental Shelf Research, 60:28-37.

Li, R., Xu, J., Li, X., Shi, Z. \& Harrison, P.J., 2017, Spatiotemporal Variability in Phosphorus Species in the Pearl River Estuary: Infuence of the River Discharge, Scientific Reports, 7:13649.

Makoto, E., Fuminori, H., Shinko, K., Jota, K. dan Hiroaki, S., 2016, Sensitive Determination of Total Particulate Phosphorus and Particulate Inorganic Phosphorus in Seawater Using Liquid Waveguide Spectrophotometry, Talanta, 153:66-70.

Maslukah, L., Wulandari, S.Y. \& Yasrida, A., 2017, Rasio Organik Karbon terhadap Fosfor dalam Sedimen di Muara Sungai Banjir Kanal Barat, Semarang, Buletin Oseanografi Marina, 6(1):3945.

Maslukah, L., Indrayanti, E. dan Budhiono, S., 2014, Proses Pasang Surut dalam Pola Fluktuasi Nutrien Fosfat di Muara Sungai Demaan, Jepara, Buletin Oseanografi Marina, 3(1):25-31.

Moriasi, D.N., Arnold, J.G., Liew, M.W.V., Binger, R.L., Harmel, R.D. \& Veith, T.L., 2007, Model Evaluation Guidelines for Systematic Quantification of Accuracy in Watershed Simulations, J. American Society of Argicultural and Biological Enginners, 50(3):885-900.

Nemery, J. dan Garnier, J., 2007, Typical Features of Particulate Phosphorus in The Seine Estuary (France), Hydrobiologia, 588:271-290.

Oktaviani, A., Yusuf, M. \& Maslukah, L., 2015, Sebaran Konsentrasi Nitrat dan Fosfat di Perairan Muara Sungai Banjir Kanal Barat, Semarang. JURNAL OSEANOGRAFI, 4(1):85-92.

Paytan, A. dan McLaughlin, K., 2007, The Oceanic Phosphorus Cycle, Chemical Reviews, 107(2):563-576.

Ruttenberg, K.C., 2003, The Global Phosphorus Cycle, Treatise on Geochemistry, 8:585-643.

Sundareshwar, P.V. \& Morris, J.T., 1999, Phosphorus Sorption Characteristics of Intertidal Marsh Sediments along An Estuarine Salinity Gradient, Limnol. Oceanogr., 44(7):1693-1701.

Tungka, A.W., Haeruddin \& Ain, C., 2016, Konsentrasi Nitrat dan Ortofosfat di Muara Sungai Banjir Kanal Barat dan Kaitannya dengan Kelimpahan Fitoplankton Harmful Alga Blooms (Habs), Indonesian Journal of Fisheries Science and Technology, 12(1):40-46.

Wulandari, S.Y., Yusuf, M. \& Muslim, 2014, Kajian Konsentrasi dan Sebaran Parameter Kualitas Air di Perairan Pantai Genuk, Semarang, Buletin Oseanografi Marina, 3(1):9-19. 
Yoshimura, T., Nishioka, J., Saito, H., Takeda, S., Tsuda, A. \& Wells, M.L., 2007, Distributions of Particulate and Dissolved Organic and Inorganic Phosphorus in North Pacific Surface Waters, Marine Chemistry, 103:112-121.

Zee, C.V.D., Roevros, N. dan Chou, L., 2007, Phosphorus Speciation, Transformation and Retention in The Scheldt Estuary (Belgium/The Netherlands) from The Freshwater Tidal Limits to the North Sea, Marine Chemistry, 106:76-91. 